\title{
Exploring the Efficacy \& Suitability of Flipped Classroom Instruction at School Level in India: A Pilot Study
}

\author{
Atasi Mohanty, Dipti Parida \\ Centre for Educational Technology, Indian Institute of Technology, Kharagpur, India \\ Email: atasi_mohanty@yahoo.in, atasim@cet.iitkgp.ernet.in
}

Received 21 January 2016; accepted 26 April 2016; published 29 April 2016

Copyright (C) 2016 by authors and Scientific Research Publishing Inc.

This work is licensed under the Creative Commons Attribution International License (CC BY).

http://creativecommons.org/licenses/by/4.0/

(c) (i) Open Access

\begin{abstract}
The objective of this study was to compare the impact of flipped mode and traditional mode of instruction, on the learning outcomes of Grade VIII school children in History and Science; 90 primary school children from Odisha (India) were randomly assigned to either of control (traditional instruction) or experimental (flipped instruction) group. Pre-test scores of both the groups were compared through " $t$ " test; the obtained " $t$ " values of -0.019 and 1.931 were found to be insignificant $(p>0.05)$ which revealed no significant difference between these groups at the beginning. Thus, both the groups were assumed to have equal variance and after 01 month their post-test scores in History and Science were again compared to examine the impact of different instructional intervention/s. The obtained " $t$ " values of both the groups' post-test scores comparisons were $-5.592,-3.260$, found to be significant at $p<0.01$ level, and confirmed the difference between control and experimental groups. Mean scores of flipped and traditional instructional groups further strengthened the positive impact of flipped mode of instruction on children's learning outcomes in History and Science. The study recommends for future work on flipped instruction with larger sample for educational implications.
\end{abstract}

\section{Keywords}

Flipped Instruction, Traditional Instruction, Learning Outcomes, History, Science

\section{Introduction}

Research on classroom lectures has demonstrated that a student's attention declines after the first 10 minutes of class, and although it may return at the end of a class, students remember only about $20 \%$ of material presented 
during the lecture. The traditional pattern of instruction use to give students the task of reading textbooks and work on problem sets outside school, while listening to lectures and taking tests in class, whereas, the flipped classroom is an innovative pedagogical approach that focuses on learner-centered instruction.

Technological innovations that have the potential to increase student learning appear daily. Some involve new, groundbreaking technologies, and others are older technologies being combined in new ways. However, one of the most popular trends in instructional technology does not involve new technology; rather it involves changing the way classroom instruction and homework are managed by reversing the traditional order of delivery. The strategy is known as flipping the classroom (also known as backwards classroom, reverse instruction, flip teaching, and reverse teaching; Wikipedia, 2013). Two high school teachers, Jonathan Bergmann and Aaron Sams, popularized the instructional strategy of a flipped classroom (Tucker, 2012). The two science teachers stumbled on the idea when they struggled to re-teach lessons for absent students. They also noticed that students who were stuck on certain homework concepts were not able to complete subsequent homework problems until they received help the next day at school (Bull, Ferster, \& Kjellstrom, 2012).

The flipped classroom strategy provides several options for differentiating instruction among students having different level of intelligence. In a flipped classroom, teachers can provide gifted and talented students with advanced content beyond their grade level. This is achieved through providing more advanced content to explore at home. The learning process is streamlined by allowing students to move through material more quickly. In flip teaching, the students first study the topic by themselves, using video lessons prepared by the teacher or third parties. In class students apply the knowledge by solving problems and doing practical work. The teacher tutors the students when they become stuck, rather than imparting the initial lesson in person. Flipped classrooms free class time for hands-on work. Students learn by doing and asking questions. Students can also help each other, a process that benefits both the advanced and less advanced learners. Flipping also changes the allocation of teacher time. Traditionally, the teacher engages with the students who ask questions but those who don't ask tend to need the most attention. Flipping allows a teacher to target those who need the most help.

\section{Flipped Instruction Model}

Over the past decades school education standards have emphasized the potential value of student-centred learning environments in which students are actively engaged in higher-order tasks and taking charge of their own learning (Hannafin, Hill, \& Land, 1997; Shea et al., 2012). Student-centred learning environments necessitate applying more active learning strategies to classroom teaching that, for example, involve student presentations, small group problem solving, self and peer evaluation, and group discussions (Zappe, Leicht, Messner, Litzinger, \& Lee, 2009). Yet, creating such environments remains a challenge. For example, teachers often have difficulties managing their finite classroom time and limited number of face to face classroom meetings to achieve an effective balance between lectures and active learning strategies (Strayer, 2012). Flipped classroom models have attempted to address these challenges by allocating more class time for active learning approaches and by leveraging accessibility to advanced technologies to support a blended learning approach. A typical flipped classroom approach provides students with access to online video lectures prior to in-class sessions so that students are prepared to participate in more interactive and higher-order activities such as problem solving, discussions, and debates (Baker, 2012; Bergmann, Overmyer, \& Wilie, 2012; Davies, Dean, \& Ball, 2013; Foertsch, Moses, Strikwerda, \& Litzkow, 2002; Fulton, 2012a; Hughes, 2012; Lage, Platt, \& Treglia, 2000; Talbert, 2012; Zappe et al., 2009). Students benefit from the outside classroom events because they can allocate their time and pace their online learning to meet their individual levels of comprehension. In face-to-face classroom sessions, students have the opportunity to become more active and interactive through group activities rather than passively listening to lectures. Teachers in turn are able to commit more in-class time to monitoring student performance and providing adaptive and instant feedback to an individual or group of students (Fulton, 2012b; Herreid \& Schiller, 2013; Hughes, 2012).

\section{Research Literature}

The flipped classroom has now become a very popular instructional model (Barseghian, 2011; Bergmann \& Sams, 2012; Tucker, 2012). A teacher survey of the impact of flipping the classroom found that teachers reported $80 \%$ of their students had improved attitudes toward school (Flipped Learning Network, 2012) that Zappe et al. (2009) experimented with a flipped undergraduate engineering class, concluding that students per- 
ceived the course as having a positive impact on their learning. Herreid \& Schiller (2013) reported the benefits of flipped classrooms based on the results of a large-scale survey, who used flipping methods. However, these reports fall short of an explicit accounting of what features of the flipped classroom yielded benefits for learners and instructors. Another recently conducted experiment (Davies et al., 2013; Strayer, 2012) indicated that there was no significant difference in student performance between flipped classrooms and traditional classrooms. Strayer (2012) reported that students perceived a significantly lower level of structural support to facilitate student conduct during flipped events, warning that this perceived lack of support might lead to lower engagement. The authors reminded that this possibility (a perceived dearth of support prior to and during a flipped event) does not indicate that the flipped classroom approach is of low value to teaching and learning. Rather, it is argued that it is necessary to explicitly define the values connected with flipped classroom models.

Flipped classrooms have been in existence for some time with variations in form and shape. Salman Khan brought this practice to mass attention through the Khan Academy, which has worked with Microsoft to record over 4400 instructional videos for its digital library to cover K-12 math, science, history, and other subjects. Many instructors practicing the flipped model have relied on these 10-min long videos in their classes, where students are instructed to watch course videos at home and do homework in school, all on a fixed schedule. The "Flipped-Mastery Classroom" is another dominant flipped learning model proposed by Bergmann \& Sams (2012), and it was developed collaboratively with students who were unable to attend regular classes, such as students in rural areas or with busy schedules. Instead of being required to watch the same instructional video on the same night before their physical class, students accessed a library of instructional videos and did not have to follow the same topic at the same time. This model provided students with flexibility in learning, so that students could choose what they learned from a wide range of resources and learn at their own pace. Nowadays, the flipped classroom has many names and approaches. Definition and coverage also vary. Bergmann \& Sams (2012) state that terms such as "blended learning”, "reverse instruction”, "inverted classroom”, and "24/7 classroom" are interchangeable, while Staker \& Horn (2012) argue that the flipped classroom is a subset of blended learning, not the equivalent. Staker \& Horn (2012) define blended learning with four different operational models: the "Rotation model," "Flex model", "Self-Blend model", and the "Enriched-Virtual model". According to this taxonomy, the Rotation-model takes place in a physical "Brick-and-Mortar" school while the Enriched-Virtual model happens in a "Pure-Virtual" space online, so the two models are at opposite ends of the spectrum, respectively. Under the Rotation-model, students still attend class at a brick and -mortar school but rotate through different modalities, such as small/large group projects, pencil-and-paper assignments, and individual tutoring. The flipped classroom, which allows the student to preview instructional material online and work through the lesson at his or her own pace; is only one of the sub-models under the Rotation-model.

\section{Conceptual Framework}

Empirical research has described the efficacy of flipped classroom from various technological aspects, for example: Strayer (2012) claim that the systematic use of interactive technology is a key feature of flipped classrooms; Bergmann \& Sams (2012) suggested a list of design considerations such as "time to learn new software" and "support from administration". However, they have failed to explain the role of instructor prior to, during and after the flipped session in enhancing performance of students.

Although researchers have developed many flipped models, each has a different focus. The traditional flipped classroom (Khan Academy) and the "Flipped Mastery Model" (Bergmann \& Sams, 2012) stress content delivery, the "Flipped Classroom Model” (Gerstein, 2011) stress learning cycles, and Staker \& Horn’s (2012) various models stress the weight of physical and virtual. Yet, all these models fail to identify how many dimensions/aspects should be considered in a flipped classroom implementation and what is the role of facilitator in enhancing the performance of school students. Research is needed on, which aspects of flipped classroom implementations explicitly benefit teaching and learning. Moreover, in school context the role of flipped instruction in enhancing different psycho-social attributes of the learner/s has not yet been empirically tried out.

From the review of literature it is evident that there is a lack of research in finding out the efficacy of flipped classroom in the context of upper-primary/secondary level/s of school education, specifically in India. More research is needed to know on what basis implementation of flipped classroom explicitly benefit teaching and learning, in comparison to the traditional mode of teaching. At the same time efficacy of flipped classroom is to be measured on students having different level of performing skills as well as its adaptability/suitability at exist- 
ing school system.

\section{Flipped Instruction: A Pilot Study}

\subsection{Research Question}

What would be the impact/s of flipped and traditional modes of instruction, on the learning outcomes of Grade VIII students in Science and History in a CBSE (Central Board of Secondary Education) pattern school in Bhubaneswar city (India)?

\subsection{Method of Study}

This study would follow a pre-test and post-test quasi-experimental design to examine the effectiveness of flipped/traditional classroom instructions in enhancing the performance of Class VIII school students in History and Science subjects.

\subsection{Sample}

In total 90 students of Class-8 from Kendriya Vidyalaya, Unit-1, Bhubaneswar, Odisha, India were selected randomly and placed in Flipped and Traditional modes of instruction ( $\mathrm{N}=45$ in each group).

\subsection{Administered Tools}

1) Flipped learning materials/videos of Class-VIII school subjects, i.e., Science \& History.

2) Pre-instruction content knowledge test and Post-instruction learning outcomes measures (designed by the researcher/s based on the Class VII \& VIII Science \& History CBSE Text books).

(Two sets of pre-test as well as post-test questions were developed in History and Science subjects of Class 7 and 8 respectively. Pre-test questions were collected from Class 7 text books and post-test questions were collected from the concerned topics of Class 8 text book/s.)

\subsection{Proposed Research Design (Figure 1)}

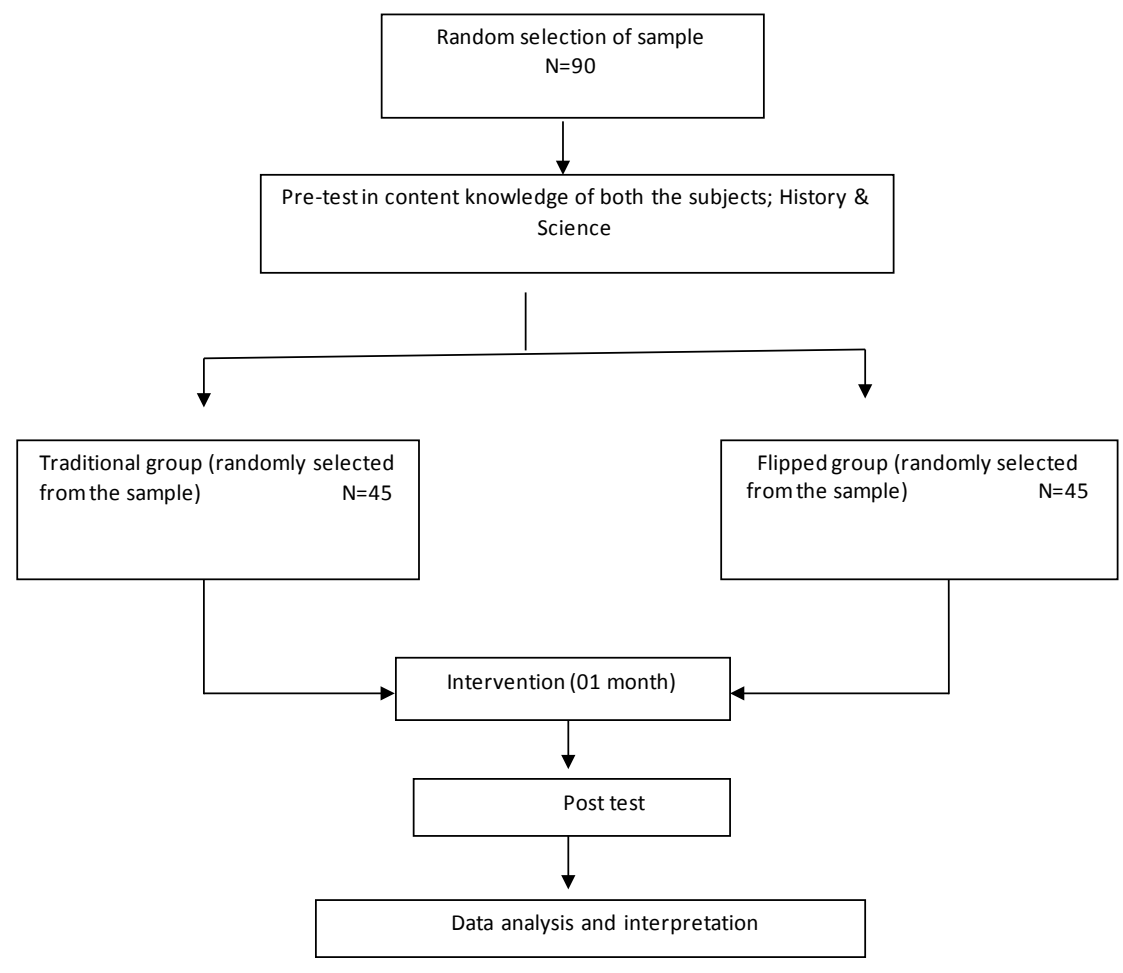

Figure 1. Flowchart of research work. 


\subsection{Procedure}

The research work was composed of 2 phases of learning situation in case of Flipped mode, but normal in Traditional mode.

First Phase: Learners study by themselves, using video lessons and hand-outs prepared by the teacher before coming to the class.

Second Phase: In-class sessions, where students participate in more interactive and higher-order activities such as problem solving, discussions, and debates. Instructor facilitates the classroom interaction and helps in accelerating the learning process. Flipped classroom strategy helps in providing differentiated instruction to students.

\subsection{Pre-Test}

Two sets of pre-test questions of 100 marks each was developed by the researcher/s from CBSE-Class VII text book of History and Science; 90 students were randomly assigned to either of Control (Traditional Instruction) or Experimental (Flipped Instruction) condition, 45 in each group. Pre-test scores of both the groups were compared through t-test.

\subsection{Intervention}

One month of intervention was given to both the groups and their responses were recorded; Group-1/Control group was taught in the traditional mode of instruction. In this group students were given the classroom lecture inside the classroom and home work was given to be done at home; Group-2/Experimental group was taught in the flipped mode of instruction. In this group students were shown the video-lectures outside the classroom and questions were provided to the students to be done at home. Inside the classroom the teacher interacted with students, discussed the content, and clarified the students' doubts. At the end of the lesson, students were assessed with a set of question of 100 marks and their responses were checked by the teacher/researcher.

\subsection{Post-Test}

After the 01 month intervention two sets of questions were developed from the concerned topics of CBSE/ClassVIII text book of 100 marks each in two Subjects, History \& Science. The Chapters chosen for the study of Science-Chapter 4-Materials: Metals and Non-Metals, Chapter 5-Coal and Petroleum; History Chapter 5-When people rebel, 1857 and After, Chapter 6-Colonialism and the city. Both the Control and Experimental groups' post test score were compared through t test.

\subsection{Data Analysis}

After the administration of above mentioned intervention and tests the collected data were analyzed both quantitatively through SPSS software, as well as qualitatively.

\subsection{Result and Interpretation}

The "T-test" was applied to measure the significance of difference between the pre-test and post-test scores of both the Traditional/Control and Flipped/Experimental groups in both the subjects. Following results were found from quantitative analysis.

\section{Major Findings}

As the Table 1 and Table 2 (Figure 2 \& Figure 3) show in pre-tests of both the subjects-History, \& Science, the " $\mathrm{t}$ " value of -0.019 in History and " $\mathrm{t}$ " value of 1.931 in Science were found to be insignificant at $p=0.01$, and $p=0.05$ levels respectively. This explains that in the beginning there was no difference between two groups, (prior to intervention) in the performance. But as the post-test scores were compared the Experimental/Flipped group performed better both in History and Science subjects. With reference to Table 3 and Table 4 (Figure 2 \& Figure 3) the " $\mathrm{t}$ " value/s of -5.592 in History and -3.260 in Science were found to be significant at $p=0.01$ level; the Post-test Mean scores also further clarify it. The Flipped mode of instruction has significantly influenced and enhanced the performance of school students at Class VIII level. 


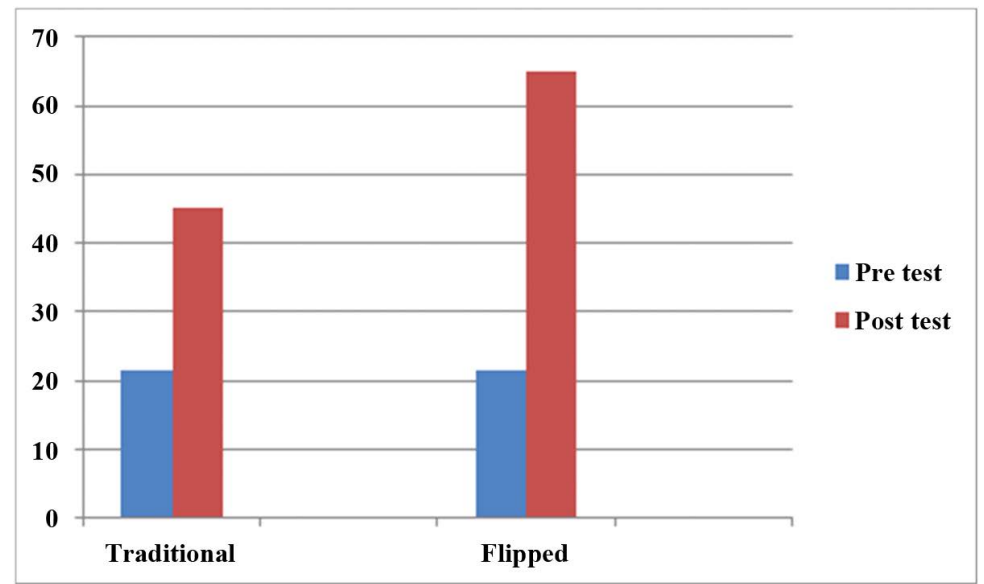

Figure 2. Mean t-test Score/s of both the groups for Subject-1 (History).

Table 1. Mean, standard deviation, \& t-values (pre-test result in History).

\begin{tabular}{ccccccccccccc}
\hline Group & $\mathrm{N}$ & Mean & $\begin{array}{c}\text { Standard } \\
\text { deviation }\end{array}$ & $\begin{array}{c}\text { Standard } \\
\text { error mean }\end{array}$ & $\begin{array}{c}\text { Pre-test } \\
\text { score }\end{array}$ & $\mathrm{t}$ & $\mathrm{df}$ & $\begin{array}{c}\text { Sig } \\
\text { difference }\end{array}$ & $\begin{array}{c}\text { Mean } \\
\text { difference }\end{array}$ & $\begin{array}{c}\text { Standard error } \\
\text { 95\% confidence interval of } \\
\text { the difference lower upper }\end{array}$ \\
\hline $\begin{array}{c}\text { Traditional } \\
\text { group }\end{array}$ & 45 & 21.3778 & 10.34691 & 1.54243 & $\begin{array}{c}\text { Equal variances } \\
\text { assumed }\end{array}$ & -0.019 & 88 & 0.985 & -0.04444 & 2.28826 & -4.59188 & 4.50299 \\
$\begin{array}{c}\text { Flipped } \\
\text { group }\end{array}$ & 45 & 21.4222 & 11.33877 & 1.69028 & $\begin{array}{c}\text { Equal variances } \\
\text { not assumed }\end{array}$ & -0.019 & 87.273 & 0.985 & -0.04444 & 2.28826 & -4.59241 \\
\hline
\end{tabular}

Table 2. Mean, standard deviation, \& t-values (pre-test result in Science).

\begin{tabular}{|c|c|c|c|c|c|c|c|c|c|c|c|c|}
\hline & $\mathrm{N}$ & Mean & $\begin{array}{l}\text { Standard } \\
\text { deviation }\end{array}$ & $\begin{array}{l}\text { Standard } \\
\text { error mean }\end{array}$ & $\begin{array}{l}\text { Pre-test } \\
\text { score }\end{array}$ & $\mathrm{t}$ & $\mathrm{df}$ & Sig & $\begin{array}{c}\text { Mean } \\
\text { difference }\end{array}$ & $\begin{array}{l}\text { Standard error } \\
\text { difference }\end{array}$ & \multicolumn{2}{|c|}{$\begin{array}{l}95 \% \text { confidence interval } \\
\text { of the difference lower upper }\end{array}$} \\
\hline $\begin{array}{l}\text { Traditional } \\
\text { group }\end{array}$ & 45 & 10.4677 & 5.07041 & 0.75585 & $\begin{array}{l}\text { Equal variances } \\
\text { assumed }\end{array}$ & 1.931 & 88 & 0.067 & 1.55778 & 0.81701 & -0.04585 & 3.20140 \\
\hline $\begin{array}{l}\text { Flipped } \\
\text { group }\end{array}$ & 45 & 8.8889 & 2.08045 & 0.31014 & $\begin{array}{l}\text { Equal variances } \\
\text { not assumed }\end{array}$ & 1.931 & 87.273 & 0.067 & 1.55778 & 0.81701 & -0.05739 & 3.21295 \\
\hline
\end{tabular}

Table 3. Mean, standard deviation, \& t-values (post-test result of History).

\begin{tabular}{|c|c|c|c|c|c|c|c|c|c|c|c|}
\hline & $\mathrm{N}$ & Mean & $\begin{array}{l}\text { Standard } \\
\text { deviation }\end{array}$ & $\begin{array}{l}\text { Standard } \\
\text { error mean }\end{array}$ & Post-test score & $\mathrm{t}$ & df & Sig & $\begin{array}{c}\text { Mean } \\
\text { difference }\end{array}$ & $\begin{array}{l}\text { Standard error } \\
\text { difference }\end{array}$ & $\begin{array}{l}95 \% \text { confidence interval } \\
\text { of the difference }\end{array}$ \\
\hline $\begin{array}{l}\text { Traditional } \\
\text { group }\end{array}$ & 45 & 45.2444 & 10.4667 & 1.52758 & $\begin{array}{c}\text { Equal variances } \\
\text { assumed }\end{array}$ & -5.592 & 88 & 0.000 & -19.64444 & 3.51280 & $-26.62540 \quad-12.66349$ \\
\hline $\begin{array}{l}\text { Flipped } \\
\text { group }\end{array}$ & 45 & 64.8889 & 21.21987 & 3.16327 & $\begin{array}{c}\text { Equal variances } \\
\text { not assumed }\end{array}$ & -5.592 & 87.273 & 0.000 & -19.64444 & 3.51280 & $-26.66322-12.62567$ \\
\hline
\end{tabular}

Table 4. Mean, standard deviation, \& t-values (post-test of Science).

\begin{tabular}{|c|c|c|c|c|c|c|c|c|c|c|c|c|}
\hline Group & $\mathrm{N}$ & Mean & $\begin{array}{l}\text { Standard } \\
\text { deviation }\end{array}$ & $\begin{array}{l}\text { Standard } \\
\text { error mean }\end{array}$ & $\begin{array}{l}\text { Post-test } \\
\text { score }\end{array}$ & $\mathrm{t}$ & df & Sig & $\begin{array}{c}\text { Mean } \\
\text { difference }\end{array}$ & $\begin{array}{l}\text { Standard error } \\
\text { difference }\end{array}$ & \multicolumn{2}{|c|}{$\begin{array}{l}95 \% \text { confidence interval } \\
\text { of the difference lower upper }\end{array}$} \\
\hline $\begin{array}{l}\text { Traditional } \\
\text { group }\end{array}$ & 45 & 19.4667 & 7.05047 & 1.05047 & $\begin{array}{c}\text { Equal variances } \\
\text { assumed }\end{array}$ & -3.260 & 88 & 0.002 & -5.75556 & 1.76541 & -9.26393 & -2.24718 \\
\hline $\begin{array}{l}\text { Flipped } \\
\text { group }\end{array}$ & 45 & 25.2222 & 25.2222 & 9.51527 & $\begin{array}{l}\text { Equal variances } \\
\text { not assumed }\end{array}$ & -3.260 & 87.273 & 0.002 & -5.75556 & 1.76541 & -9.26808 & -2.24303 \\
\hline
\end{tabular}

\section{Discussion \& Conclusion}

It is evident from the above findings that the flipped mode of instruction has significant impact on the learning outcomes of students in subjects like Science (more practical) and History (more theoretical) in comparison to 


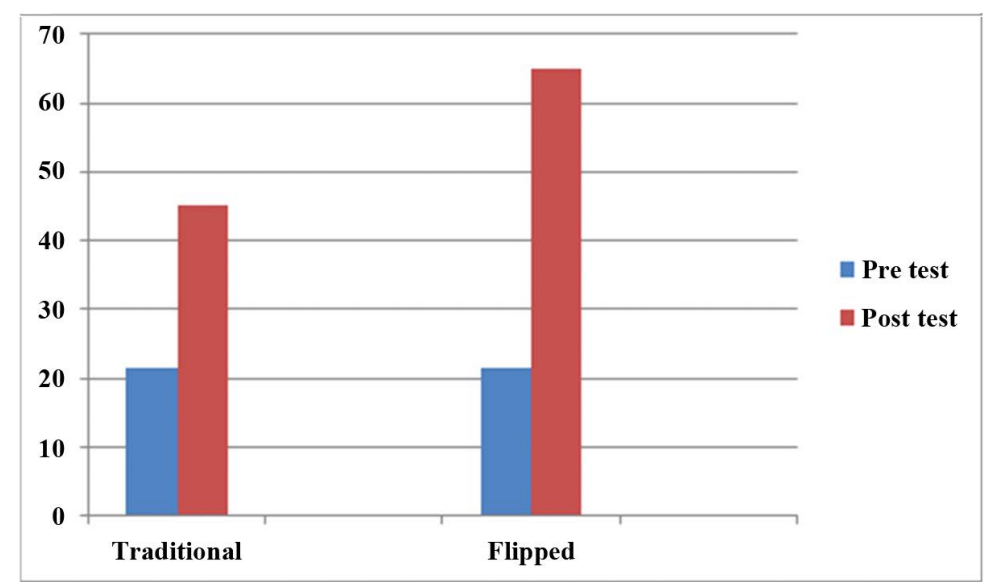

Figure 3. Mean t-test Score/s of both the groups for Subject-2 (Science).

the existing traditional mode of instruction being provided by the CBSE (Central Board Of Secondary Education) pattern Kendriya Vidyalaya, in an urban city Bhubaneswar, where children are better exposed to ICT. However, we cannot generalize the findings because of small sample size. In spite of this limitation this study throws some light on certain pedagogical issues; such as flipped instruction allows the students to learn the material at their own pace, can reverse back and relearn for mastery; as a result students with varying learning abilities get motivated and engaged in the self-learning activities. Subsequently, during the classroom discussions, with the facilitators' interventions and brainstorming questions students get further benefitted. Moreover, the subject teachers also get enough time and opportunity to give individual attention, clarify the doubts of everyone and match the instruction with every learner's need/s. But in case of ongoing traditional method, these were absent. Even though the Kendriya Vidyalayas follow the CCA (Continuous Comprehensive Evaluation) pattern, it becomes very difficult on the part of the teacher/instructor to individualize his/her instruction as per the students' requirements. Thus, the students end up with completing the assignments, prepare the textbook questions as per the examination (Summative or Formative) patterns, nothing beyond that. As a result, regular classroom learning becomes boring, monotonous to them.

Even though, many empirical works/studies have already proven the positive impact of flipped instruction at higher education, teacher education levels, very few attempts have been made at school level. Recently, Marks (2015) has advocated for flipped instruction in Teacher education citing the advantages of proactive planning, blended pedagogy, streamlined online courses and learner's active engagements for adult learners/teacher trainees, but can we really replicate these at school level. Researchers have categorically highlighted on the strengths of active and collaborative learning, problem-based and project based learning through flipped mode of instruction at the university level, which significantly enhance the learners' engagements and performances ( $\mathrm{Du}, \mathrm{Fu}, \&$ Wang, 2014). However, they were quite unsure about its long term impact on traditional colleges and universities with interdisciplinary subjects. Prior to this, Dumont (2014) had combined flipped classrooms with peer instructions in Applied Science subjects in Swiss University and found higher level of conceptual reasoning, mastery learning and satisfactory learning experiences in case of students and deeper engagements with better role satisfaction among faculty members. But, when Bell (2015) tried to assess the impact of flipped classroom instruction at high school level, he didn't found statistically significant difference, from traditional instructions in terms of students' attitude towards classroom environment/interactions. Clark (2015) had compared the flipped and traditional modes in secondary level Mathematics classroom and found that students were more engaged, experienced quality instruction, felt the improvement in their studies but didn't differ significantly in performance. The reason may be, Math as a subject demands more rigorous practice, but the flipped mode has the potentiality for higher learning engagements. In Social Science, studies at Putnam High School in Connecticut, Driscoll (2013) uploaded the recording lectures and institutional videos in Vimeo and You Tube and tried the flipped method; students were able to view the videos at home, with class time devoted for home works, assignments and group activities. But despite this effort (due to many reasons), many students couldn't succeed significantly and many others learnt the content only at superficial level. Thus, he added/suggested additional teaching methods like mastery learning, monitoring and blended these with other materials/tools, supported/ 
guided the students for setting their own goals for managing time, taking ownership of their own learning etc. After that significant improvement took place; 83\% students reported of active and experiential learning and $76 \%$ reported of autonomy and learning key skills and concepts.

In the present study also the researchers have tried to give individualized instruction, autonomy to students to learn at their own pace in the computer labs (outside the regular classroom), which was not available in the usual traditional method of teaching. Instead of giving them the videos to go through at home, the instructor insisted upon playing these in the computer labs with PCs in her presence. This ensured the students self-learning and exploration of contents prior to classroom discussions. Probably this practice has given us a positive impact of flipped instruction, even with small sample size. However, in our future work we need to explore the students' self-regulated learning skills which can mediate their learning experiences and performances. In a case study, on flipped classrooms in secondary level Mathematics at Byron High School in Minnesota, USA (2009) the researchers found significant improvements in the Math chapters/contents on calculus, pre-calculus and algebra among students (up to 89.0, 86.6 and 98.0 out of 100) in "Peer Instruction Flip" mode in comparison to "traditional flip" or "lecture mode" of instruction. By 2011 the percentage of students passing the state (Math) test had increased to $78.8 \%$ and the school's average ACT (total) composite score had improved to $24.5 \%$. Here, one more dimension like peer instruction (apart from facilitator's/instructor's intervention) has emerged as an important contributing factor. Thus, if we can use flipped instruction more flexibly and strategically, it can incur many advantages; such as

a) As students sit prepared for the class they can look at the lecture in other prospective and actively get involved in the classroom discussions;

b) As this mode of teaching involves more of practical activity, students feel more engaged and motivated than traditional mode;

c) There is no problem with the pace of the teacher. Students can view the lecture/video materials as many times as they want, can take many breaks and reflect upon these with more queries. But here the real challenges are:

Preparation of contents/video lectures/materials in a very scientific pedagogic way with more personalized feedback system. The instructional videos should be short and interactive, so that the students shouldn't feel bored in absence of a tutor. Flipped mode along with other techniques like more classroom instruction time, practical activity and peer tutoring can enhance the engagements, motivation and performance of school children.

Hence, we as the researchers need to further explore how the school children at different developmental stages develop the self-learning skills, meta-cognitive strategies and self-awareness. Moreover, a whole gamut of infrastructure/technological access/facilities/e-learning contents and well-trained expert teachers are required for running the flipped classrooms in our CBSE pattern schools, not as the substitute but as supplementary/ complementary to the traditional classroom teaching. Currently, some of the International Schools are practicing these as a part of smart classes/learning programmes, but quite few in number and quite expensive for rural school children or common middle class parents. Hence, the Government, Corporate and NGOs can collaborate/ venture into this to update/enrich our school education system.

\section{Implications}

1) Academic courses can be redesigned for better learning engagements.

2) School teachers can be educated for content knowledge improvement and pedagogical skill acquisition.

It can be used as multi-modal learning tool for experiential learning.

\section{References}

Baker, C. (2012). Flipped Classrooms: Turning Learning Upside Down: Trend of “Flipping Classrooms” Helps Teachers to Personalize Education. Deseret News.

http://www.deseretnews.com/article/765616415/Flipped-classrooms-Turning-learning-upside-down.html?pg=all

Barseghian, T. (2011). Three Trends That Define the Future of Teaching and Learning, KQED.

Bell, M.R. (2015). An Investigation of the Impact of a Flipped Classroom Instructional Approach on High School Students' Content Knowledge and Attitudes towards the Learning Environment. BYU Scholars Archive, Provo: Brigham Young University. 
Bergmann, J., \& Sams, A. (2012). Flip Your Classroom: Reach Every Student in Every Class Every Day. International Society for Technology in Education.

Bergmann, J., Overmyer, J., \& Wilie, B. (2012). The Flipped Class: Myths vs. Reality (1 of 3). The Daily Riff-Be Smarter. About Education.

Bull, G., Ferster, B., \& Kjellstrom, W. (2012). Connected Classroom-Inventing the Flipped Classroom. Learning and Leading with Technology, 40, 10.

Hamdan, N., McKnight, P., McKnight, K., \& Arfstrom, K. M. (2013). A Review of Flipped Learning. http://www.flippedlearning.org/review

Clark, K. R. (2015). The Effects of the Flipped Model of Instruction on Student Engagement and Performance in the Secondary Mathematics Classroom. Texas, USA: Midwestern State University.

Davies, R. S., Dean, D. L., \& Ball, N. (2013). Flipping the Classroom and Instructional Technology Integration in a College-Level Information Systems Spreadsheet Course. Education Technology Research and Development, 61, 563-580. http://dx.doi.org/10.1007/s11423-013-9305-6

Driscoll, T. (2013). EDU on Go and Flipped Learning Enable Putnam High School Teacher to Empower Students. https://www.google.co.in/webhp?sourceid=chrome-instant\&ion=1\&espv=2\&ie=UTF-8\#q=Driscoll\%2C+T.+(2013).+ED U+on+Go+and+Flipped+Learning+Enable+Putnam+High+School+Teacher+to+Empower+Students

Du, S.-C., Fu, Z.-T., \& Wang, Y. (2014). The Flipped Classroom-Advantages and Challenges. International Conference on Economic Management and Trade Cooperation, China Agricultural University, Beijing, 2014, 17-20.

Dumont, A. (2014). Implementing the Flipped Classrooms and Peer Instruction in a Swiss University of Applied Sciences. Western Switzerland: University of Applied Sciences and Arts.

Foertsch, J., Moses, G., Strikwerda, J., \& Litzkow, M. (2002). Reversing the Lecture/Homework Paradigm Using eTeach ${ }^{\circledR}$ Web-Based Streaming Video Software. Journal of Engineering Education, 91, 267-274.

http://dx.doi.org/10.1002/j.2168-9830.2002.tb00703.x

Fulton, K. (2012a). Inside the Flipped Classroom. http://thejournal.com/articles/2012/04/11/the-flipped-classroom.aspx

Fulton, K. (2012b). Upside Down and Inside Out: Flip Your Classroom to Improve Student Learning. Learning \& Leading Technology, 39, 12-17.

Gerstein, J. (2011). The Flipped Classroom Model: A Full Picture.

https://www.google.co.in/webhp?sourceid=chrome-instant\&ion=1\&espv=2\&ie=UTF-8\#q=.+Gerstein\%2C+J.+(2011).+Th e+Flipped+Classroom+Model:+A+Full+Picture

Hannafin, M., Hill, J., \& Land, S. (1997). Student-Centered Learning and Interactive Multimedia: Status, Issues, and Implication. Contemporary Education, 68, 94-99.

Herreid, C. F., \& Schiller, N. A. (2013). Case Studies and the Flipped Classroom. Journal of Nutrition Education and Behaviour, 47, 109-114.

Hughes, H. (2012). Introduction to Flipping the College Classroom. World Conference on Educational Multimedia, Hypermedia and Telecommunications, 2012, 2434-2438.

Lage, M. J., Platt, G. J., \& Treglia, M. (2000). Inverting the Classroom: A Gateway to Creating an Inclusive Learning Environment. The Journal of Economic Education, 31, 30-43. http://dx.doi.org/10.1080/00220480009596759

Marks, D. B. (2015). Flipping the Classroom: Turning an Instructional Methods Course Upside Down. Journal of College Teaching \& Learning, 12, 241-248. http://dx.doi.org/10.19030/tlc.v12i4.9461

Shea, P., Hayes, S., Smith, S. U., Vickers, J., Bidjerano, T., Pickett, A., \& Jian, S. (2012). Learning Presence: Additional Research on a New Conceptual Element within the Community of Inquiry (CoI) Framework. http://dx.doi.org/10.1016/j.iheduc.2011.08.002

Staker, H., \& Horn, M. B. (2012). Classifying K-12 Blended Learning. http://WWW.INNOSIGHTINSTITUTE.ORG

Strayer, J. F. (2012). How Learning in an Inverted Classroom Influences Cooperation, Innovation and Task Orientation. Learning Environments Research, 15, 171-193. http://dx.doi.org/10.1007/s10984-012-9108-4

Talbert, R. (2012). Inverted Classroom. The Internet and Higher Education, 15, 89-95.

Tucker, B. (2012). The Flipped Classroom. Education Next, 12, No. 1. http://educationnext.org/the-flipped-classroom/

Zappe, S., Leicht, R., Messner, J., Litzinger, T., \& Lee, H. (2009). “Flipping” the Classroom to Explore Active Learning in a Large Undergraduate Course. Proceedings of the 2009 American Society for Engineering Education Annual Conference and Exhibition. 